\title{
PENINGKATAN PENDAPATAN DENGAN METODE PENJUALAN E-COMMERCE DAN TRADISIONAL PT BATIK SIDA MUKTI
}

\author{
Pandaya $^{1}$, Suyatmi $^{2}$, Imam Suprapta $^{3 *}$ \\ 1,2,3 Sekolah Tinggi Ilmu Ekonomi Muhammadiyah Jakarta, pandaya965@gmail.com; \\ suyatmi1091@gmail.com; suprapta2017@gmail.com*(Corresponding Author)
}

\begin{abstract}
ABSTRAK
Metode penjualan konvesional mulai kehilangan pembeli akibat dampak dari Covid-19, sementara metode penjualan e-commerce belum efektif karena masih terbatasnya kemampuan SDM pada PT Batik Sida Mukti. Penelitian ini dilakukan untuk mengetahui bukti empiris pengaruh metode penjualan e-commerce, metode penjualan konvensional terhadap peningkatan pendapatan pada PT Batik Sida Mukti.

Sampel penelitian ini sebanyak 60 responden yang diambil menggunakan teknik purposive sampling. Penelitian ini menggunakan variabel independen metode penjualan $e$ commerce dan penjualan konvensional, sementara variabel dependen yang digunakan adalah peningkatan pendapatan.

Hasil penelitian menunjukkan pengaruh positif dan signifikan antara metode penjualan $e$ commerce dan metode penjualan konvensional terhadap peningkatan pendapatan. Serta keduanya juga berpengaruh secara simultan terhadap peningkatan pendapatan pada PT Batik Sida Mukti. Berdasarkan hasil yang didapat kedua variabel memberikan pengaruh terhadap peningkatan pendapatan. Oleh karena itu PT Batik Sida Mukti harus meningkatkan dan memperluas jaringan e-commerce-nya. Serta memberikan pelatihan kepada karyawannya agar lebih kompeten menghadapi era serba digital. Keuntungan menggunakan platform e-commerce yaitu mempunyai jaringan lebih luas, sehingga penjualan menjadi lebih efektif dan bisa menjangkau berbagai tempat. Perusahaan juga perlu memperbanyak promosi seperti melakukan program diskon di event-event tertentu untuk lebih menarik minat pelanggan baik secara langsung maupun online.
\end{abstract}

Kata kunci: Penjualan E-commerce, Penjualan Konvensional, Peningkatan pendapatan.

\begin{abstract}
Conventional sales methods are starting to lose buyers due to the impact of Covid-19, while e-commerce sales methods are not yet effective due to the limited human resources at PT Batik Sida Mukti. This study was conducted to find out empirical evidence of the effect of ecommerce sales methods, conventional sales methods on increasing revenue at PT Batik Sida Mukti.

The sample of this study was 60 respondents who were taken using purposive sampling technique. This study uses the independent variables of e-commerce sales methods and conventional sales, while the dependent variable used is an increase in income.

The results showed a positive and significant effect between e-commerce sales methods and conventional sales methods on increasing revenue. And both of them also have a
\end{abstract}


simultaneous effect on increasing revenue at PT Batik Sida Mukti. Based on the results obtained, the two variables have an effect on increasing income. Therefore, PT Batik Sida Mukti must improve and expand its e-commerce network. As well as providing training to its employees to be more competent in facing the digital era. The advantage of using an e-commerce platform is that it has a wider network, so sales become more effective and can reach various places. Companies also need to increase promotions such as conducting discount programs at certain events to attract more customers, both directly and online.

Keywords: E-commerce Sales, Conventional Sales, Increased revenue.

Naskah diterima : 12-11-2021, Naskah dipublikasikan : 30-11-2021

\section{PENDAHULUAN}

Seluruh bisnis dituntut untuk lebih cepat dalam memenuhi kebutuhan konsumen di era serba digital saat ini. Hal ini disebabkan persaingan yang semakin meningkat antar perusahaan yang menggunakan produk sejenis. Banyak cara yang diupayakan untuk meningkatkan penjualan produk dan menjaga kelangsungan hidup perusahaan. Selain kualitas produk, aspek layanan juga menjadi pertimbangan konsumen. Pelayanan tidak hanya cepat, akurat, efisien dan praktis, tetapi juga pelayanan yang memuaskan konsumen. Tidak sedikit perusahaan yang bangkrut karena tidak mampu memenuhi permintaan konsumen. Oleh sebab itu perusahaan harus mulai mengembangkan strategi baru untuk mempertahankan pelanggan lama dan menarik pelanggan baru.

Salah satu strategi yang ditawarkan adalah penggunaan aplikasi $e$-commerce sebagai fitur pemasaran, penjualan dan layanan terintegrasi yang bertujuan untuk meningkatkan jumlah konsumen dan pendapatan. Pandemi Covid-19 saat ini mendorong masyarakat Indonesia untuk segera memasuki era Industri 4.0. Banyak UMKM sudah memanfaatkan e-commerce dan aplikasi digital untuk menjual atau memperdagangkan barang serta memonitor stok mereka. Bahkan sudah bertambah banyak masyarakat yang berbelanja secara online (daring). Dengan begitu telah membuat e-commerce di tanah air semakin tumbuh dan berkembang.

Strategi penjualan konvensional yang dilakukan harus memiliki aspek keahlian berdagang karena penjual harus memiliki pengetahuan tentang produk dan menguasai seni menjual, seperti cara mendekati pelanggan, memberikan presentasi dan promo. Penjual juga harus memiliki kemampuan untuk bernegosiasi dan melakukan komunikasi yang efektif dengan setiap karakter individu calon pembeli. Pada dasarnya penjualan secara konvensional masih banyak diminati, karena transaksi ini mengharuskan pembeli dan penjual bertemu sehingga dapat melihat secara langsung barang yang diperjual belikan. Dengan begitu tingkat kepercayaan pembeli menjadi lebih tinggi, apalagi dengan pelayanan yang baik maka akan menarik banyak pelanggan (Hermawan, 2017).

Karyawan yang menjadi pelaksana dalam meningkatkan penjualan produk dengan strategi yang ditetapkan perusahaan juga menjadi salah satu faktor dalam menentukan naik turunnya pendapatan. Karyawan yang baik adalah karyawan yang mampu memberikan kontribusi terhadap perusahaan, tidak hanya tenaga tapi juga pikiran, ide, improvement agar semua yang mereka kerjakan bisa mendapatkan hasil maksimal baik dari segi kualitas, kuantitas dan efisiensi waktu. Karyawan perlu berperan aktif dalam mengimplementasikan strategi yang ada agar dapat memberikan manfaat bagi perusahaan.

PT Batik Sida Mukti selama ini masih konsisten menerapkan metode penjualan secara konvensional yaitu melakukan penjualan secara langsung melalui galeri/toko atau countercounter yang ada di beberapa mall di Jakarta. Hal ini karena produk yang mereka jual adalah hasil 


\section{JURNAL AKUNTANSI, Vol. 10, No. 2, November (2021)}

kerajinan batik sehingga para pelanggan atau pembeli akan lebih tertarik apabila melihat secara langsung bahan dan motif batik yang akan mereka beli.

Penelitian ini mencoba mengetahui pengaruh dari metode penjualan e-commerce dan metode penjualan konvensional pada PT Batik Sida Mukti. Apakah keduanya berpengaruh terhadap peningkatan pendapatan perusahaan.

Penelitian sebelumnnya yang dilakukan Megawati (2015) menyatakan bahwa nilai tingkat kepuasan pengguna terhadap penjualan konvensional lebih besar dibandingkan dengan pengguna penjualan online. Penelitian yang dilakukan oleh Sa'ad (2017) dan Helmalia (2018) menunjukan bahwa metode penjualan e-commerce berpengaruh terhadap peningkatan pendapatan, berbeda dengan penelitian yang dilakukan Putri (2019) yang menyatakann bahwa penjualan e-commerce tidak berpengaruh signifikan terhadap peningkatan pendapatan.

\section{KAJIAN LITERATUR}

\section{Penjualan}

Menurut Basu Swasta (2015) penjualan adalah ilmu dan seni mempengaruhi pribadi yang dilakukan oleh penjual untuk mengajak orang lain agar bersedia membeli barang dan jasa yang ditawarkan. Pengertian lain diungkapkan oleh Winardi (2016) bahwa penjualan adalah proses dimana sang penjual memuaskan segala kebutuhan dan keinginan pembeli agar dicapai manfaat baik bagi sang penjual maupun sang pembeli yang berkelanjutan dan yang menguntungkan kedua belah pihak.

Tujuan Penjualan menurut Basu Swasta (2015) ada tiga, yaitu :

a. Volume penjualan tertentu.

b. Mendapatkan laba tertentu.

c. Menunjang pertumbuhan perusahaan.

Sementara bentuk-bentuk dari penjualan adalah sebagai berikut:

a. Penjualan tunai

Penjualan tunai dilaksanakan oleh perusahaan dengan cara mewajibkan pembeli melakukan pembayaran harga barang terlebih dahulu sebelum barang diserahkan oleh perusahaan kepada pembeli (Mulyadi, 2013).

b. Penjualan Kredit

Penjualan kredit dilaksanakan oleh perusahaan dengan cara mengirimkan barang sesuai dengan order yang diterima dari pembeli dan untuk jangka waktu tertentu perusahaan mempunyai tagihan kepada pembeli tersebut (Mulyadi, 2013).

Menurut Basu Swastha (2015) ada beberapa faktor yang dapat mempengaruhi kegiatan penjualan yaitu :

a. Kondisi dan kemampuan penjual

b. Kondisi Pasar

c. Modal 

d. Kondisi organisasi perusahaan
e. Faktor lain

\section{Penjualan Konvensional (Langsung)}

Penjualan langsung (offline) merupakan metode penjualan yang dilakukan dengan cara menjual dan memasarkan produk langsung ke konsumen di luar lokasi tetap penjualan eceran. Penjual secara langsung adalah dimana penjual dan pembeli beratatap muka atau berhubungan secara langsung. Menurut Buchari (2018) penjualan langsung sebagai penjualan yang dilakukan secara demonstran atau dari pintu ke pintu, penjualan di tempat pertemuan, misal di perkantoran, di rumah atau di lokasi yang telah ditentukan sebelumnya oleh penjual kepada konsumen. Penjualan adalah bagian dari promosi dan promosi adalah salah satu bagian dari keseluruhan sistem pemasaran. (Abdullah dan Francis, 2016).

Asosiasi Penjualan Langsung Indonesia (APLI) mendefinisikan bahwa terdapat dua bentuk jenis penjualan secara langsung antara lain:

a. Single Level Marketing (Pemasaran Satu Tingkat)

Metode ini merupakan metode dimana produsen melakukan pemasaran barang atau jasa melalui program pemasaran berbentuk satu tingkat, yang mana para mitra usaha mendapatkan komisi dari penjualan dan bonus dari hasil penjualan barang dan jasa yang dilakukannya sendiri.

b. Multi Level Marketing (Pemasaran Multi Tingkat)

Berbeda dengan single marketing jenis MLM ini sering kita dengar dimasyarakat karena merupakan jenis yang cukup populer, dimana pemasaran barang atau jasa berbentuk lebih dari satu tingkat, dimana mitra usaha mendapatkan komisi penjualan dan bonus penjualan dari hasil penjualan barang atau jasa yang dilakukannya sendiri dan anggota jaringan di dalam kelompoknya.

Kelebihan dari penjualan konvensional ini adalah :

a. Bisa menawarkan produk secara langsung pada konsumen.

b. Memungkinkan penjual mendapatkan feedback secara langsung dalam bentuk kritik, saran, ataupun pertanyaan.

c. Dapat membujuk konsumen.

d. Dapat memberikan informasi yang kompleks mengenai produk yang ingin dijual.

e. Mampu meningkatkan jumlah penjualan dengan segera.

Kekurangan dari penjualan langsung adalah:

a. Membutuhkan biaya yang besar (biaya transportasi dsb)

b. Membutuhkan banyak tenaga dan banyak waktu 


\section{Penjualan E-commerce}

Penjualan dengan metode online adalah aktivitas penjualan yang mencari calon pembeli sampai memberikan bentuk perhatian kepada konsumen dengan memanfaatkan seperangkat alat elektronik dengan menggunakan jaringan internet sebagai penghubungnya. Menurut Turban et al., (2015) E-commerce adalah proses membeli, menjual, memperdagangkan data, barang, dan jasa melalui media internet. E-commerce memiliki definisi sebagai transaksi komersil yang melibatkan pertukaran nilai dengan teknologi atau menggunakan teknologi digital antar individu (Laudon dan Traver, 2017).

Ajeet Khurana dalam tulisanya yang berjudul Types Of E-commerce (dalam I Putu Agus Eka, 2015), mengungkapkan adanya empat jenis kategori didalam e-commerce saat ini. Keempat jenis e-commerce tersebut antara lain :
a. Business to Business (B2B)
b. Business to Consumer (B2C)
c. Consumer to Consumer $(C 2 C)$
d. Consumer to Busines (C2B)

Komponen atau pilar pendukung e-commerce menurut Turban et al. (2015) adalah sebagai berikut:
a. Manusia
b. Kebijakan publik
c. Pemasaran dan periklanan
d. Layanan pendukung
e. Kemitraan bisnis

\section{Pendapatan}

Pendapatan dari kegiatan normal perusahaan biasanya diperoleh dari hasil penjualan barang ataupun jasa yang berhubungan dengan kegiatan utama perusahaan. Pendapatan yang bukan berasal dari kegiatan normal perusahaan adalah hasil di luar kegiatan utama perusahaan yang sering disebut hasil non operasi. Pendapatan non operasi biasanya dimasukkan ke dalam pendapatan lain-lain, misalnya pendapatan bunga dan deviden.

Menurut Diana dan Setiawati (2017) Pendapatan merupakan aliran masuk bruto dari manfaat ekonomi yang timbul dari aktivitas normal entitas selama suatu periode jika arus masuk tersebut mengakibatkan kenaikan ekuitas yang bukan berasal dari kontribusi penanaman modal. Pengertian penghasilan (income) menurut Kartikahadi, dkk (2016) adalah kenaikan manfaat ekonomi selama satu periode akuntansi dalam bentuk pemasukan atau penambahan aset atau penurunan kewajiban yang mengakibatkan kenaikan ekuitas yang tidak berasal dari kontribusi penanam modal.

Sumber-sumber pendapatan menurut Greuning, et al. (2013) berasal dari:
a. Penjualan barang
b. Pemberian jasa 
c. Penggunaan aset entitas oleh entitas lain yang menghasilkan bunga

d. Royalti

e. Dividen

Menurut Ikatan Akuntan Indonesia (2019) pendapatan dapat timbul dari transaksi dan kejadian berikut ini:
a. Penjualan barang
b. Penjualan jasa, dan
c. Penggunaan aset entitas oleh pihak lain yang menghasilkan bunga royalti dan dividen".

\section{Omset Penjualan}

Kata Omset berarti jumlah, sedang penjualan berarti kegiatan menjual barang yang bertujuan mencari laba/pendapatan. Jadi omzet penjualan berarti Jumlah penghasilan/laba yang diperoleh dari hasil menjual barang/jasa. Omzet penjualan merupakan keseluruhan jumlah pendapatan yang didapat dari hasil penjulan suatu barang atau jasa dalam kurun waktu tertentu (Chaniago dalam Khuriyati, 2013).

Alex S, Nitisemito (2014) mengemukakan bahwa faktor penyebab turunnya omzet penjualan meliputi dua faktor yaitu:

a. Fakor Intern

Turunnya omzet penjualan dapat terjadi karena kesalahan perusahaan itu sendiri yang dibagi kedalam beberapa bagian antara lain: kualitas produk turun, service yang diberikan bertambah jelek, sering kosongnya persediaan barang, penurunan komisi penjualan yang diberikan, pengetatan terhadap piutang yang diberikan, turunnya kegiatan salesmen, penurunan kegiatan sales promotion dan penetapan harga jual yang tinggi.

b. Faktor Ekstern

Turunnya omzet penjualan dapat terjadi diluar kekuasaan perusahaan itu sendiri yang di bagi kedalam beberapa bagian: perubahan selera konsumen, munculnya saingan baru, munculnya barang pengganti, pengaruh faktor psycologis, perubahan atau tindakan baru dalam kebijaksanaan pemerintah, adanya tindakan dari pesaing.

\section{Kerangka Pemikiran}

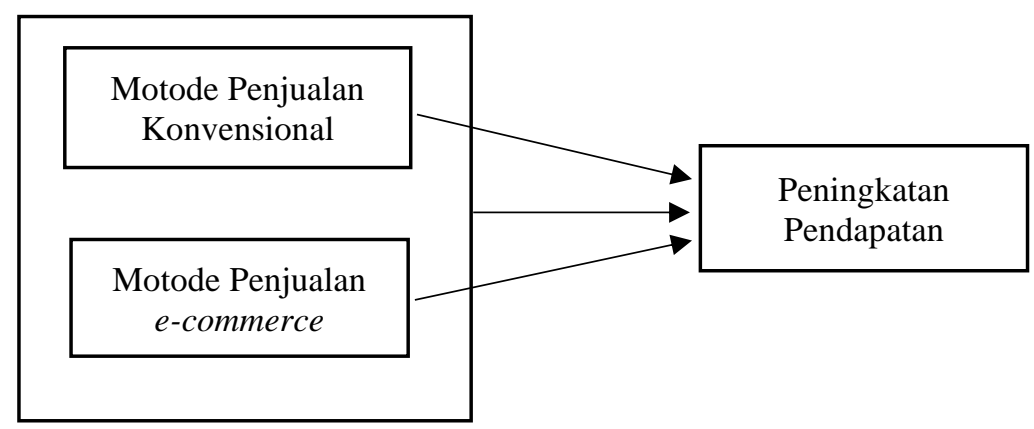

Gambar 1. Kerangka Pemikiran 


\section{METODE PENELITIAN}

\section{Populasi dan Sampel}

Populasi dalam penelitian ini adalah para karyawan PT Batik Sida Mukti yang berperan aktif dalam mengimplementasikan strategi dengan metode penjualan konvensional dan metode penjuallan e-commerce yang berjumlah 83 orang. Berdasarkan jumlah populasi yang terdapat pada PT Batik Sida Mukti Jakarta yang berjumlah 83 orang karyawan maka sampel yang digunakan adalah sampel populasi. Sampel yang dipilih sekitar 60 orang karyawan, tehnik pengambilan sampel adalah dengan purposive sampling.

\section{Pengumpuan Data}

Penelitian ini menggunakan metode pengumpulan data dengan metode kuesioner. Pengumpulan data dilakukan dengan memberi pertanyaan tertulis kepada karyawan di PT Batik Sida Mukti, Skala pengukuran penelitian ini yang digunakan adalah likert, dimana setiap item pertanyaan disediakan lima jawaban sehingga data dapat dihitung.

\section{METODE ANALISIS DATA}

\section{Analisis Deskriptif}

Deskritif kuantitatif dilakukan untuk menjawab pertanyaan penelitian yaitu menganalisis pengaruh antar variabel. Setelah data terkumpul tahap selanjutnya adalah tahap analisis. Dalam tahap analisis penulis menggunakan sebuah aplikasi untuk mengolah data yaitu SPSS versi 25 .

Namun sebelum tahap analisis data dilakakukan maka penulis perlu menguji apakah data tersebut valid dan reable. Uji ini dilakukan untuk meninjau seberapa valid suatu butir-butir pertanyaan yang diajukan kepada responden atau yang dikenal uji validitas, serta mengukur tingkat reabilitas suatu jawaban responden dari suatu instrument pertanyaan dengan metode uji reabilitas. Dimana metode penjualan e-commerce (variabel X1), metode penjualan konvensional (variabel X2) dan Peningkatan pendapatan pada PT Batik Sida Mukti (variabel Y).

Dan Berikut adalah beberapa uji yang harus dilakukan :

\section{Uji Kualitas Data}

a. Uji Validitas

Menurut Rully Indrawan (2014) Validitas menguji instrument yang dipilih, apakah memiliki tingkat ketepatan, untuk mengukur apa yang semestinya diukur atau tidak. Lebih lanjut Sugiyono (2018:93) mengatakan Instrumen yang valid berarti alat ukur yang digunakan untuk mendapatkan data (mengukur) itu valid. Valid berarti instrumen tersebut dapat digunakan untuk mengukur apa yang hendak diukur.

Adapun kriteria penilaian uji validitas adalah :

1) Apabila $r$ hitung $>r$ tabel, maka item kuisioner tersebut valid.

2) Apabila $r$ hitung < r tabel, maka item kuisioner tersebut tidak valid.

\section{b. Uji Reliabilitas}

Menurut Ghozali (2018) yang dimaksud uji reliabilitas atau keandalan suatu instrumen penelitian digunakan untuk mengetahui adanya konsistensi alat ukur dalam penggunaannya. 
Reliabilitas adalah instrument untuk mengukur ketepatan, keterandalan, consistency, stability atau dependability terhadap alat ukur yang digunakan. Suatu alat ukur dikatakan reliabilitas atau dapat dipercaya, apabila alat ukur yang digunakan stabil, dapat diandalkan, dan dapat digunakan dalam peramalan. Artinya data yang dikatakan reliabilitas adalah alat ukur yang digunakan bisa memberikan hasil yang sama walaupun digunakan berkali-kali oleh peneliti yang berbeda.

Instrumen dikatakan reliabel untuk mengukur variabel bila memilki nilai Cronbach Alpha> 0,70.

\section{Uji Asumsi Klasik}

a. Uji Normalitas Data

Menurut Ghozali (2018: 161) Uji normalitas data digunakan untuk menguji apakah data terdistribusi normal atau tidak. Data yang baik adalah data yang terdistribusi normal. Uji normalitas bertujuan untuk menguji apakah dalam sebuah model regresi, variable dependen, variable independen atau keduanya mempunyai distribusi normal atau tidak.

Uji normalitas dapat dilakukan dengan analisis grafik normal p-plot atau uji statistik menggunakan uji Kolmogorov-Smirnov. Dalam penelitian ini, uji normalitas dilakukan dengan melakukan uji statistik Kolmogorov-Smirnov. Uji Kolmogorov- Smirnov dilakukan dengan menguji nilai unstandardized residual. Uji Kolmogorov- Smirnov dilakukan dengan membuat hipotesis:

$\mathrm{H} 0$ : data residual berdistribusi normal

HA : data residual tidak berdistribusi normal

Pengambilan keputusan :

1) Jika nilai signifikansi $<0,05$ maka distribusi adalah tidak normal

2) Jika nilai signifikansi $>0,05$ maka distribusi adalah normal

b. Uji Multikolinearitas

Uji multikolinearitas menurut Ghozali (2018:107) pengujian multikolinearitas bertujuan untuk mengetahui apakah dalam model regresi ditemukan adanya korelasi antar variabel independen atau tidak. Uji multikolinearitas digunakan untuk mengetahui apakah model regresi tersebut baik atau tidak. Model regresi akan dikatakan baik apabila tidak terdapat hubungan antar variabel independennya.

Menurut Ghozali (2018:108), Kriteria yang digunakan untuk melihat apakah terdapat gejala multikolinearitas atau tidak, yaitu:

1) Nilai tolerance $\leq 0,10$ atau sama dengan nilai VIF $\geq 10$, maka terdapat gejala multikolinearitas.

2) Nilai tolerance $\geq 0.10$ atau sama dengan nilai $\mathrm{VIF} \leq 10$, maka tidak terdapat gejala multikolinearitas.

\section{c. Uji Heteroskedastisitas}

Uji heteroskedasititas bertujuan untuk menguji apakah model regresi terjadi ketidaksamaan varians dari residuall satu pengamatan ke pengamatan yang lain (Ghozali, 2018: 137). Pengujian heteroskedastisitas dapat dilakukan dengan cara analisis grafik dan uji statistic. Dalam penelitian ini, pengujian heteroskedastisitas menggunakan uji statistic yaitu dengan uji 
glejser. Uji geljser dilakukan dengan menguji nilai absolut residualnya terhadap variabel independen.

Dasar pengambilan keputusan uji glejser yaitu:

1) Jika nilai signifikansi > 0,05, maka tidak terjadi heteroskedastisitas

2) Jika nilai signifikansi $<0,05$, maka terjadi heteroskedastisitas

\section{Analisis Regresi Linear Berganda}

Analisis regresi linear berganda digunakan untuk mengetahui arah dan seberapa besar pengaruh variabel independen terhadap variabel dependen (Ghozali, 2018:95).

Hasil dari analisis regresi linear berganda akan menguji seberapa besar pengaruh metode penjualan e-commerce, metode penjualan konvensional terhadap peningkatan pendapatan pada PT Batik Sida Mukti. Persamaan regresi linier berganda biasanya dinyatakan dalam persamaan sebagai berikut:

$$
\mathrm{Y}=\alpha+\beta 1 \mathrm{X} 1+\beta 2 \mathrm{X} 2+\varepsilon
$$

Dimana :

$\mathrm{Y}=$ Peningkatan Pendapatan

$\alpha \quad=$ Nilai konstanta (alpha)

$\beta=$ Koefisien regresi

$\mathrm{X} 1$ = Metode Penjualan E-commerce

$\mathrm{X} 2$ = Metode Penjualan Konvensional

$\varepsilon \quad=$ error (Kesalahan)

\section{Uji Hipotesis}

a. Uji R2 (Koefisien Determinasi)

Koefisien determinasi (R2) pada intinya mengukur seberapa jauh kemampuan model dalam menerangkan variasi variabel dependen. Nilai koefisien determinasi adalah antara nol dan satu. Nilai R2 yang kecil berarti kemampuan variabel-variabel independen dalam menjelaskan variasi variabel-variabel dependen amat terbatas. Nilai yang mendekati satu berarti variabel-variabel independen memberikan hampir semua informasi yang dibutuhkan untuk memprediksi variasi variabel dependen. Kelemahan mendasar penggunaan koefisien determinasi adalah bias terhadap jumlah variabel independen yang dimasukan ke dalam model penelitian. Oleh karena itu banyak peneliti menganjurkan untuk menggunakan adjusted R2 saat mengevaluasi mana model regresi terbaik. Nilai adjusted R2 dapat naik atau turun apabila satu variabel independen ditambahkan ke dalam model penelitian (Ghozali, 2018).

Rumus koefisien determinasi (Kd) yaitu:

$$
\mathrm{Kd}=\mathrm{R} 2 \times 100 \%
$$

Keterangan:

$\mathrm{Kd}=$ Koefisien determinasi 


\section{b. Uji t (Signifikansi Parameter Individual)}

Menurut Ghazali (2018: 98) Uji t digunakan untuk menunjukkan seberapa jauh pengaruh satu variabel penjelas/independen secara individual dalam menerangkan variasi variabel dependen. Pengujian menggunakan signifikansi level 0,05 $(\alpha=5 \%)$. Dengan kriteria sebagai berikut:

1) Jika nilai sig. $\leq 0,05$ maka dikatakan signifikan. Harus dilihat terlebih dahulu nilai koefisien regresinya, jika arahnya sesuai dengan arah hipotesis maka dapat dikatakan Ha diterima.

2) Jika nilai sig. $>0,05$ maka dikatakan tidak signifikan. Artinya Ha ditolak sehingga tidak ada pengaruh variabel independen terhadap variabel dependen.

Maka rumus Uji t yaitu :

Keterangan:

$\mathrm{t}=$ Nilai Uji $\mathrm{t}$

$r=$ Koefisien korelasi

$r 2=$ Koefisien determinasi

$\mathrm{n}=$ Jumlah sampel

\section{c. Uji F (Kelayakan Model)}

Menurut Sugiyono (2018:192) yang dimaksud dengan Uji F adalah Terdapat hubungan yang positif dan pengaruh antara variabel bebas terhadap variabel terikat. Untuk menguji apakah masing-masing variabel bebas berpengaruh secara signifikan terhadap variabel terikat secara bersama-sama dengan $\alpha=0,05$. Maka rumus Uji F yaitu:

Keterangan:

R2 = Koefisien Determinasi

$\mathrm{k}=$ Jumlah Variabel Independen

$\mathrm{n} \quad=$ Jumlah Anggota Sampel

Jika signifikan $\mathrm{F}<0.05$ maka H0 ditolak artinya variabel independen secara simultan berpengaruh terhadap variabel independen. Sebaliknya, jika F > 0.05 maka H0 diterima artinya variabel independen secara simultan tidak berpengaruh terhadap variabel dependen.

\section{PEMBAHASAN}

\section{Analisis Deskriptif}

Tabel 1. Hasil statistic deskriptif

\begin{tabular}{rr|r|r|r|r}
\multicolumn{7}{c}{ Descriptive Statistics } \\
\hline & N & Minimum & Maximum & Mean & $\begin{array}{c}\text { Std. } \\
\text { Deviation }\end{array}$ \\
\hline X1 & 60 & 26 & 48 & 38,45 & 5,519 \\
\hline X2 & 60 & 29 & 49 & 39,31 & 4,115 \\
\hline
\end{tabular}




\begin{tabular}{cr|r|r|r|r}
\hline & N & Minimum & Maximum & Mean & $\begin{array}{c}\text { Std. } \\
\text { Deviation }\end{array}$ \\
\hline Y & 60 & 12 & 25 & 19,76 & 2,813 \\
\hline Valid N (listwise) & 60 & & & & \\
\hline
\end{tabular}

(Sumber: SPSS diolah tahun 2021)

Berdasarkan Tabel 1 diketahui bahwa jumlah data setiap variabel yang valid sebesar 60 , dari 60 sampel metode penjualan e-commerce (X1), nilai minimum sebesar 26, nilai maksimum 49 , nilai mean sebesar 38,45, nilai standar deviasi sebesar 5,519. Artinya nilai mean > nilai standar deviasi sehingga penyimpangan data yang terjadi rendah maka penyebaaran nilainya merata.

Metode penjualan konvensional (X2), nilai minimum sebesar 48, nilai maksimum 49, nilai mean sebesar 39,31, nilai standar deviasi sebesar 4,115. Artinya nilai mean > nilai standar deviasi sehingga penyimpangan data yang terjadi rendah maka penyebaran nilainya merata.

Peningkatan pendapatan $(\mathrm{Y})$, nilai minimum sebesar 12 , nilai maksimum 25 , nilai mean sebesar 19,76, nilai standar deviasi sebesar 2,813. Artinya nilai mean > nilai standar deviasi sehingga penyimpangan data yang terjadi rendah maka penyebaran nilainya merata.

\section{Uji Kualitas Data}

a. Uji Validitas

Tabel 2. Hasil Uji Validitas Item-Item Variabel

\begin{tabular}{llllc}
\hline & $\begin{array}{c}\text { Pearson } \\
\text { Correlation }(\mathrm{R} \\
\text { Hitung) }\end{array}$ & R Tabel & $\begin{array}{c}\text { Sig. (2- } \\
\text { tailed })\end{array}$ & Keterangan \\
\hline X1.1 & 0,704 & 0,254 & 0,000 & Valid \\
X1.2 & 0,770 & 0,254 & 0,000 & Valid \\
X1.3 & 0,522 & 0,254 & 0,000 & Valid \\
X1.4 & 0,538 & 0,254 & 0,000 & Valid \\
X1.5 & 0,741 & 0,254 & 0,000 & Valid \\
X1.6 & 0,342 & 0,254 & 0,007 & Valid \\
X1.7 & 0,646 & 0,254 & 0,000 & Valid \\
X1.8 & 0,620 & 0,254 & 0,000 & Valid \\
X1.9 & 0,616 & 0,254 & 0,000 & Valid \\
X1.10 & 0,700 & 0,254 & 0,000 & Valid
\end{tabular}




\begin{tabular}{|c|c|c|c|c|}
\hline & $\begin{array}{c}\text { Pearson } \\
\text { Correlation (R } \\
\text { Hitung) }\end{array}$ & R Tabel & $\begin{array}{l}\text { Sig. (2- } \\
\text { tailed) }\end{array}$ & Keterangan \\
\hline $\mathrm{X} 2.1$ & 0,590 & 0,254 & 0,000 & Valid \\
\hline $\mathrm{X} 2.2$ & 0,638 & 0,254 & 0,000 & Valid \\
\hline $\mathrm{X} 2.3$ & 0,523 & 0,254 & 0,000 & Valid \\
\hline X2.4 & 0,406 & 0,254 & 0,001 & Valid \\
\hline $\mathrm{X} 2.5$ & 0,388 & 0,254 & 0,002 & Valid \\
\hline X2.6 & 0,683 & 0,254 & 0,000 & Valid \\
\hline $\mathrm{X} 2.7$ & 0,573 & 0,254 & 0,000 & Valid \\
\hline $\mathrm{X} 2.8$ & 0,672 & 0,254 & 0,000 & Valid \\
\hline X2.9 & 0,314 & 0,254 & 0,014 & Valid \\
\hline $\mathrm{X} 2.10$ & 0,574 & 0,254 & 0,000 & Valid \\
\hline Y.1 & 0,787 & 0,254 & 0,000 & Valid \\
\hline Y.2 & 0,733 & 0,254 & 0,000 & Valid \\
\hline Y.3 & 0,848 & 0,254 & 0,000 & Valid \\
\hline Y.4 & 0,626 & 0,254 & 0,000 & Valid \\
\hline Y.5 & 0,858 & 0,254 & 0,000 & Valid \\
\hline
\end{tabular}

Berdasarkan hasil pengujian validitas pada tabel diatas, kuesioner yang berisi dari 3 variabel ini terdapat 25 kuesioner yang telah diisi oleh 60 responden. Diketahui bahwa $r$ tabel dari 60 responden dengan tingkat signifikansi 0,05 atau $5 \%$ adalah 0,254 . Jadi karena $r$ hitung $>0,254$ dan tingkat signifikansi 0,05 , maka data dinyatakan valid.

b. Uji Reliabilitas

Tabel 3. Hasil pengujian reliabiltas terhadap variabel metode penjualan $e$-commerce

\section{Reliability Statistics}

\begin{tabular}{cc} 
Cronbach's Alpha & N of Items \\
\hline 0,826 & 10 \\
\hline
\end{tabular}

(Sumber: SPSS diolah tahun 2021) 
Berdasarkan tabel 3 terkait dari uji reliabilitas pada variabel metode penjualan ecommerce (X1) dapat diketahui bahwa nilai cronbach's alpha $0,826>0,60$, dari hasil tersebut membuktikan bahwa semua pertanyaan kuisioner dinyatakan reliabel.

Tabel 4. Hasil pengujian reliabilitas terhadap variabel metode penjualan konvensional

\begin{tabular}{cc}
\hline \multicolumn{2}{c}{ Reliability Statistics } \\
Cronbach's Alpha & N of Items \\
\hline 0,729 & 10 \\
\hline
\end{tabular}

(Sumber: SPSS diolah tahun 2021)

Berdasarkan tabel 4 terkait dari uji reliabilitas pada variabel metode penjualan konvensional (X2) dapat diketahui bahwa nilai cronbach's alpha 0,729 >0,60, dari hasil tersebut membuktikan bahwa semua pertanyaan kuisioner dinyatakan reliabel.

Tabel 4. Hasil pengujian reliabilitas terhadap variabel peningkatan pendapatan

\begin{tabular}{cr}
\hline \multicolumn{2}{c}{ Reliability Statistics } \\
Cronbach's Alpha & N of Items \\
\hline 0,823 & 5 \\
\hline
\end{tabular}

(Sumber: SPSS diolah tahun 2021)

Berdasarkan tabel 5 terkait dari uji reliabilitas pada variabel peningkatan pendapatan (Y) dapat diketahui bahwa nilai cronbach's alpha $0,823>0,60$, dari hasil tersebut membuktikan bahwa semua pertanyaan kuesioner dinyatakan reliabel

\section{Uji Asumsi Klasik}

a. Uji Normalitas Data

Tabel 5. Hasil uji normalitas data

One-Sample Kolmogorov-Smirnov Test

\begin{tabular}{ccr}
\hline & & $\begin{array}{c}\text { Unstandardized } \\
\text { Residual }\end{array}$ \\
\hline Normal Parameters $^{\mathrm{a}, \mathrm{b}}$ & Mean & 60 \\
& Std. Deviation &, 000000 \\
& Absolute & 0,21237837 \\
& &
\end{tabular}




\section{JURNAL AKUNTANSI, Vol. 10, No. 2, November (2021)}

\begin{tabular}{ccr}
\hline & & $\begin{array}{c}\text { Unstandardized } \\
\text { Residual }\end{array}$ \\
\hline Most Extreme & Positive & 0,053 \\
Differences & Negative & $-0,101$ \\
& & 0,101 \\
Test Statistic & $0,199^{\mathrm{c}}$ \\
Asymp. Sig. (2-tailed)
\end{tabular}

(Sumber: SPSS diolah tahun 2021)

Berdasarkan table 6 dapat diketahui bahwa nilai signifikansi adalah 0,199>0,05. Jadi artinya bahwa data berdistribusi normal.

b. Uji Multikolinearitas

Tabel 6. Hasil uji multikolinearitas

\begin{tabular}{|c|c|c|c|c|c|c|c|c|}
\hline \multicolumn{9}{|c|}{ Coefficients $^{\mathrm{a}}$} \\
\hline & \multicolumn{3}{|c|}{$\begin{array}{l}\text { Unstandardize } \\
\text { d Coefficients }\end{array}$} & \multirow{2}{*}{$\begin{array}{c}\text { Standardiz } \\
\text { ed } \\
\text { Coefficient } \\
\mathrm{s} \\
\\
\text { Beta }\end{array}$} & \multirow[b]{2}{*}{$\mathrm{T}$} & \multirow[b]{2}{*}{ Sig. } & \multicolumn{2}{|c|}{$\begin{array}{l}\text { Collinearity } \\
\text { Statistics }\end{array}$} \\
\hline & Model & B & $\begin{array}{l}\text { Std. } \\
\text { Error }\end{array}$ & & & & $\begin{array}{l}\text { Toleran } \\
\text { ce }\end{array}$ & VIF \\
\hline 1 & $\begin{array}{c}\text { (Constant } \\
\text { ) }\end{array}$ & 4,040 & 2,828 & & 1,429 & 0,159 & & \\
\hline & $\mathrm{X} 1$ & 0,122 & 0,086 & 0,240 & 1,415 & 0,162 & 0,377 & $\begin{array}{r}2,65 \\
2\end{array}$ \\
\hline & $\mathrm{X} 2$ & 0,280 & 0,116 & 0,410 & 2,417 & 0,019 & 0,377 & $\begin{array}{r}2,65 \\
2\end{array}$ \\
\hline
\end{tabular}

(Sumber: SPSS diolah tahun 2021)

Berdasarkan tabel 7 dapat diketahui bahwa nilai tolerance metode penjualan $e$ commerece (X1) adalah $0,377>0,10$ dan nilai VIF 2,652 < 10,00. Sementara itu nilai tolerance metode penjualan konvensional (X2) adalah 0,377>0,10 dan nilai VIF 2,652< 10,00.. Maka dapat disimpulkan bahwa tidak terjadi masalah multikolinearitas dalam regresi. 


\section{JURNAL AKUNTANSI, Vol. 10, No. 2, November (2021)}

c. Uji Heteroskedastisitas

Tabel 7. Hasil uji heteroskedastisitas

\section{Coefficients $^{\text {a }}$}



(Sumber: SPSS diolah tahun 2021)

Berdasarkan tabel 8 dapat diketahui bahwa nilai signifikansi metode penjualan $e$ commerce (X1) 0,882 > 0,05 dan metode penjualan konvensional (X2) 0,236>0,05. Maka dapat disimpulkan bahwa tidak terjadi masalah heteroskedastisitas.

\section{Analisis Regresi Linear Berganda}

Tabel 8. Hasil pengujian regresi linear berganda

\section{Coefficients $^{\mathrm{a}}$}

\begin{tabular}{|c|c|c|c|c|c|c|}
\hline & \multirow[b]{2}{*}{ Model } & \multicolumn{2}{|c|}{$\begin{array}{l}\text { Unstandardized } \\
\text { Coefficients }\end{array}$} & \multirow{2}{*}{$\begin{array}{l}\text { Standardiz } \\
\text { ed } \\
\text { Coefficient } \\
\text { s } \\
\text { Beta }\end{array}$} & \multirow[b]{2}{*}{$\mathrm{T}$} & \multirow[b]{2}{*}{ Sig. } \\
\hline & & B & Std. Error & & & \\
\hline \multirow[t]{3}{*}{1} & (Constant) & 4,040 & 2,828 & & 1,429 & , 159 \\
\hline & $\mathrm{X} 1$ & ,122 & ,086 &, 240 & 1,415 & , 162 \\
\hline & $\mathrm{X} 2$ & ,280 & , 116 & ,410 & 2,417 & ,019 \\
\hline
\end{tabular}

(Sumber: SPSS diolah tahun 2021)

$\mathrm{Y}=\mathrm{a}+\mathrm{b} 1 . \mathrm{X} 1+\mathrm{b} 2 . \mathrm{X} 2$

$\mathrm{Y}=4,040+0,122+0,280$ 


\section{JURNAL AKUNTANSI, Vol. 10, No. 2, November (2021)}

Berdasarkan tabel 9 diketahui bahwa 4,040 merupakan konstanta atau keadaan dimana variabel peningkatan pendapatan belum dipengaruhi oleh variabel lain yaitu metode penjualan $e$ commerce (X1) dan metode penjualan konvensional (X2) tidak ada maka peningkatan pendapatan pada PT Batik Sida Mukti tidak mengalami perubahan.

B1 (nilai koefisien regresi X1) sebesar 0,122. Artinya setiap kenaikan 1 satuan variabel metode penjualan e-commerce maka akan mempengaruhi peningkatan pendapatan sebesar 0,122 . dan B2 (nilai koefisien regresi X2) sebeesar 0,280. Artinya setiap kenaikan 1 satuan variabel metode penjualan konvensional maka akan mempengaruhi peningkatan pendapatan sebesar 0,280. Dengan asumsi tidak dipengaruhi oleh variabel lain.

\section{Uji Hipotesis}

a. Uji R2 (Koefisien Determinasi)

Tabel 9. Hasil pengujian koefisien determinasi

Model Summary

\begin{tabular}{rr|r|r|r}
\hline Model & R & R Square & \multicolumn{1}{c}{$\begin{array}{c}\text { Adjusted R } \\
\text { Square }\end{array}$} & \multicolumn{1}{c}{$\begin{array}{l}\text { Std. Error of } \\
\text { the Estimate }\end{array}$} \\
\hline 1 &, $617^{\mathrm{a}}$ &, 381 &, 360 & 2,25086 \\
\hline
\end{tabular}

(Sumber: SPSS diolah tahun 2021)

Berdasarkan tabel 10 dipengaruhi nilai koefisien $R$ square $\left(\mathrm{R}^{2}\right)$ sebesar 0,381 atau $38,1 \%$. Jadi bisa diambil kesimpulan bahwa besarnya pengaruh variabel metode penjualan $e$ commerce (X1) dan metode penjualan konvensional (X2) terhadap peningkatan pendapatan (Y) sebesar 38,1\%

b. Uji t (Signifikansi Parameter Individual)

Tabel 10. Hasil uji t terhadap variabel metode penjualan e-commerce

\section{Coefficients $^{\mathbf{a}}$}

\begin{tabular}{|c|c|c|c|c|c|c|}
\hline \multirow{2}{*}{\multicolumn{2}{|c|}{ Model }} & \multicolumn{2}{|c|}{$\begin{array}{l}\text { Unstandardized } \\
\text { Coefficients }\end{array}$} & \multirow{2}{*}{$\begin{array}{c}\text { Standardized } \\
\text { Coefficients } \\
\text { Beta } \\
\end{array}$} & \multirow[b]{2}{*}{$\mathrm{T}$} & \multirow[b]{2}{*}{ Sig. } \\
\hline & & B & Std. Error & & & \\
\hline \multirow[t]{2}{*}{1} & $\begin{array}{c}\text { (Constant } \\
\text { ) }\end{array}$ & 8,719 & 2,147 & & 4,062 & ,000 \\
\hline & X1_Total & , 287 &, 055 & ,564 & 5,199 &, 000 \\
\hline
\end{tabular}

(Sumber: SPSS diolah tahun 2021) 


\section{JURNAL AKUNTANSI, Vol. 10, No. 2, November (2021)}

Berdasarkan tabel 11 diketahui bahwa nilai t hitung sebesar 5,199>2,002, maka artinya $\mathrm{H} 0$ ditolak dan $\mathrm{H} 1$ diterima, yang artinya metode penjualan e-commerce (X1) berpengaruh terhadap peningkatan pendapatan (Y).

Tabel 11. Hasil uji t terhadap variabel metode penjualan konvensional

\section{Coefficients $^{\mathrm{a}}$}

\begin{tabular}{|c|c|c|c|c|c|c|}
\hline \multirow{2}{*}{\multicolumn{2}{|c|}{ Model }} & \multicolumn{2}{|c|}{$\begin{array}{l}\text { Unstandardized } \\
\text { Coefficients }\end{array}$} & \multirow{2}{*}{$\begin{array}{c}\text { Standardized } \\
\text { Coefficients } \\
\text { Beta }\end{array}$} & & \multirow[b]{2}{*}{ Sig. } \\
\hline & & B & Std. Error & & & \\
\hline \multirow[t]{2}{*}{1} & $\begin{array}{c}\text { (Constant } \\
\text { ) }\end{array}$ & 3,653 & 2,839 & & 1,287 & ,203 \\
\hline & $\mathrm{X} 2$ & ,410 & ,072 & 600 & 5,706 & ,000 \\
\hline
\end{tabular}

(Sumber: SPSS diolah tahun 2021)

Berdasarkan tabel 12 nilai t hitung sebesar 5,706 > 2,002, maka artinya H0 ditolak dan H1 diterima, yang artinya metode penjualan konvensional (X2) berpengaruh terhadap peningkatan pendapatan $(\mathrm{Y})$.

c. Uji F (Kelayakan Model)

Tabel 12. Hasil uji F

ANOVA $^{\mathrm{a}}$

\begin{tabular}{llr|r|r|r|r}
\hline \multicolumn{2}{l}{ Model } & $\begin{array}{c}\text { Sum of } \\
\text { Squares }\end{array}$ & Df & \multicolumn{1}{c}{$\begin{array}{c}\text { Mean } \\
\text { Square }\end{array}$} & \multicolumn{1}{c}{ F } & \multicolumn{1}{c}{ Sig. } \\
\hline 1 & Regression & 177,951 & 2 & 88,975 & 17,562 &, $000^{\mathrm{b}}$ \\
\cline { 2 - 7 } & Residual & 288,782 & 57 & 5,066 & & \\
\hline & Total & 466,733 & 59 & & & \\
\hline
\end{tabular}

(Sumber: SPSS diolah tahun 2021)

Berdasarkan tabel 13 diketahui bahwa nilai $\mathrm{F}$ hitung sebesar 17,562 > 3,160 (F tabel). Maka H0 ditolak dan H1 diterima, yang artinya metode penjualan e-commerce (X1) dan metode penjualan konvensional (X2) secara simultan berpengaruh terhadap peningkatan pendapatan pada PT Batik Sida Mukti. 


\section{PENUTUP}

\section{Simpulan}

Berdasarkan hasil penelitian dan pembahasan dapat ditarik kesimpulan bahwa Metode penjualan e-commerce berpengaruh terhadap peningkatan pendapatan pada PT Batik Sida Mukti. Hal ini menunjukkan bahwa e-commerce mampu menarik minat konsumen, sehingga makin bertambahnya tingkat pendapatan. Metode penjualan konvensional berpengaruh terhadap peningkatan pendapatan. Hal ini menunjukkan bahwa metode konvensional masih memiliki daya tarik dan kemampuan dalam menarik minat pelanggan sehingga mampu meningkatkan pendapatan perusahaan. Metode penjualan e-commerce dan metode penjualan konvensional berpengaruh secara simultan terhadap peningkatan pendapatan pada usaha PT Batk Sida Mukti.

\section{Saran}

Berdasarkan hasil penelitian, maka dapat diberikan saran-saran sebaiknya pihak PT. Batik Sida Mukti terus meningkatkan penjualan baik dengan metode konvensional maupun melalui metode e-commerce untuk meningkatkan pendapatan perusahaan. Dengan menerapkan metode konvensional calon pembeli dapat melihat jenis kain dan motif secara langsung. Keuntungan menggunakan platform e-commerce yaitu mempunyai jaringan lebih luas, sehingga penjualan menjadi lebih efektif dan bisa menjangkau berbagai tempat. Perusahaan juga perlu memperbanyak promosi seperti melakukan program diskon di event-event tertentu untuk lebih menarik minat pelanggan baik secara lsngsung maupun online. Untuk meningkatkan kemampuan karyawan, PT. Batik Sida Mukti perlu memberikan pelatihan agar lebih berkompeten dalam mengikuti tren di era teknologi yang semakin canggih.

Penelitian ini perlu dikembangkan lagi oleh peneliti selanjutnya untuk mendapatkan hasil yang lebih baik. Peneliti selanjutnya diharapkan menambahkan variabel-variabel lain yang diduga mampu mempengaruhi dalam meningkatan pendapatan perusahaan. Saran disusun berdasarkan temuan penelitian yang telah dibahas. Saran dapat mengacu pada tindakan praktis, pengembangan teori baru, dan/atau penelitian lanjutan.

\section{REFERENSI}

Abdullah, Thamrin dan Francis Tantri. (2016). Manajemen Pemasaran. Depok: PT Raja Grafindo Persada.

Agus, Hermawan. (2017). Komunikasi Pemasaran. Jakarta: Erlangga.

Alex S, Nitisemito. (2014). Manajemen Personalia. Jakarta: Ghalia Indonesia.

Alma H. Buchari. (2018). Manajemen Pemasaran dan Pemasaran Jasa. Bandung: Alfabeta.

Anastasia Diana dan Lilis Setiawati. (2017). Akuntansi Keuangan Menengah. Yogyakarta: Andi Offset

Basu Swastha Dharmmesta. (2015). Manajemen Pemasaran. BPFE: Yogyakarta.

Ghozali, I (2018). Aplikasi Analisis Multivariete. SPSS 25 (pth ed.). Semarang; Universitas Diponegoro

Greuning, Hennie Van. et al. (2013). International financial reporting Standards : Sebuah Panduan Praktis. Jakarta: Salemba Empat.

Hans Kartikahadi, dkk. (2016). Akuntansi Keuangan Berdasarkan SAK Berbasis IFRS Buku 1. Jakarta: Salemba Empat. 
Helmalia, H., \& Afrinawati, A. (2018). Pengaruh e-commerce terhadap peningkatan pendapatan usaha mikro kecil dan menengah di Kota Padang. JEBI (Jurnal Ekonomi Dan Bisnis Islam), 3(2), 237-246.

Ikatan Akuntansi Indonesia. (2019). Standar Akuntansi Keuangan Entitas Tanpa Akuntabilitas Publik (SAK ETAP). Dewan Standar Akuntansi Keuangan, Jakarta.

Indrawan, Rully. (2014). Metodologi Penelitian Kualitatif, Kuantitatif dan Campuran. Surabaya: Refika Aditama.

Khuriyati, T. (2013). Faktor-Faktor Penyebab Penurunan Omzet Penjualan Pada Industri Kerajinan Monel di Desa Kriyan Kabupaten Jepara (Doctoral dissertation, Universitas Negeri Semarang).

Laudon, K. C., \& Traver, C. G. (2017). E-Commerse 2016 Business, Tecnology, Sociey (12th ed.). England: Britis Library Cataloguint-in.

Megawaty (2015) ANALISIS TINGKAT KEPUASAN PENGGUNA PERBANDINGAN ANTARA PENJUALAN KONVENSIONAL DENGAN PENJUALAN SECARA ONLINE. In: SNIT 2015, 23 Mei 2015, Bina Sarana Informatika (BSI).

Mulyadi. (2013). Sistem Akuntansi (Edisi Ketiga), Cetakan Keempat Jakarta: Salemba Empat.

Pratama, I Putu Agus Eka. (2015). E-Commerce, E-Business Dan Mobile Commerce Berbasiskan Open Source. Bandung: Informatika.

Putri, L. R. (2019). PENGARUH PENJUALAN ONLINE DAN OFFLINE TERHADAP TINGKAT PENJUALAN DALAM PERSPEKTIF ETIKA BISNIS ISLAM (Studi pada Ladyfame Shop di Bandar Lampung) (Doctoral dissertation, UIN Raden Intan Lampung).

Sa'ad, W. N. (2017). Pengaruh e-commerce terhadap peningkatan pendapatan sentra industri keripik pisang Bandarlampung ditinjau dari etika bisnis Islam (Studi pada sentra industri keripik pisang di Kota Bandarlampung) (Doctoral dissertation, UIN Raden Intan Lampung).

Sugiyono. (2018). Metode Penelitian Kuantitatif, Kualitatif dan R\&D. Bandung: PT Alfabet.

Turban, Efraim. et. al. (2015). Electronic commerce a Managerial and Social Networks Perspective (8th ed). Springer.

Winardi. (2016). Kepemimpinan dalam Manajemen. Jakarta. 